\title{
Desertification and population health in the Turkmenistan part of the Aral Sea region
}

\author{
N. Orlovsky ${ }^{1}$, V. Radzinsky ${ }^{2} \&$ L. Orlovsky ${ }^{1}$ \\ ${ }^{I} J$. Blaustein Institute for Desert Research, Ben-Gurion University of the \\ Negev,Israel \\ ${ }^{2}$ Russian University of People's Friendship, Moscow, Russia
}

\section{Abstract}

The main causes of desertification in the Aral Sea Basin are the regulating of flow of Amudarya and Syrdarya rivers resulted in the sharp reduction of the Aral Sea level, subsequent change of regional climate towards aridization and continentality, increase of irrigation and drinking water mineralization, pollution of surface and ground water by municipal wastes and the residues of agrochemicals, deposition of salts transferred from the exposed and dried bottom of the Aral Sea. The high level of water, air and soil pollution in combination with extreme climatic conditions inevitably affect the health of women and children leading to unfavorable outcomes of pregnancy and births, health problems of infants and children, and women of fertile age. The results of 5-year study on influence of environmental factors on health of women and children in Dashkhovuz velayat of Turkmenistan are presented.

\section{Introduction}

The characteristic feature of the ecological conditions on the eve of new age and millenium is anthropogenic pressure on nature not limited by small areas, but extended to the vast regions of the globe. In some of these areas the changes of environment are not significant and don't endager the vital activities of the local population. These areas represent the zones of "ecological risk". The especially unfavorable environment has been formed in the areas where the natural dynamic equilibrium was significantly disturbed by human activities. One of such regions is the Aral Sea Basin, where the processes of desertification has 
being developing as a result of large-scale irrigation program. Especially unfavorable ecological conditions have been formed in the area surround the Aral Sea.

The Dashkhovuz velayat (province) of Turkmenistan, one of the Newly Independent Central Asian States, is one of the most affected by the Aral crisis areas. It is situated in the northeast of Turkmenistan and occupies 71.7 thousand $\mathrm{km}^{2}$ of the ancient and modern Amudarya River delta. The population of the province is 892,000 , the most of it $(68 \%$ or 600,000$)$ is rural population [1]. It is concentrated in the oases or irrigated lands within the total area more than 409 thousand hectares. The irrigated lands of Dashkhovus constitute more than one quarter of the arable lands in Turkmenistan. One third part of the Turkmen cotton, more than $80 \%$ of rice, $50 \%$ of the corn are cultivated here. It gives $20 \%$ of the silk cocoons of the country.

Excessive introduction of moisture holding crops (rice, cotton) is a destabilizing ecological factor of the region. Moreover, the irrational use of pesticides and mineral fertilizers in the irrigated lands has led to the pollution of irrigation and drinking water, and food. All these factors are hazardous to the health of the population, particular children's and mother's health.

The main goal of the study is to show the impact of degraded environment caused by desertification processes on the health of population of the Dashkhovuz province of Turkmenistan.

\section{Causes of desertification}

Desertification is defined as "land degradation in drylands resulting from various factors, including climatic variations and human activities" [2]. "Land" in this concept includes soil, local water resources, as well as natural vegetation and crops. "Degradation" means the reduction of resource potential by one or combination of processes acting on the land.

The desertification of the Aral Sea Basin has been caused by a tremendous nature-reconstructing plan. It includes the development of the large-scale irrigation agriculture, cultivation of cotton and rice in the desert areas using the water of the Amudarya and Syrdarya rivers. For implementation of this plan a large cotton-producing center was established, and the production of raw cotton in the Central Asia rapidly increased. However, along with the increase in the water consumption for the large-scale irrigation agriculture, the area of Aral Sea began to decrease. Towards the 1999 the sea level dropped more than $18 \mathrm{~m}$, and comes now to the mark of $33.8 \mathrm{~m}$ MSL. The width of the exposed and dried bottom exceeds $120 \mathrm{~km}$, and its total area is about 40,300 square $\mathrm{km}$ [3]. The Aral Sea is disappearing from the Earth in the space of one human generation, and in its place the youngest in the world's sandy-solonchak desert "Aralkum" is forming. The exposed and dried bottom of the sea is strongly saline. The sulfate and chloride salts cover huge areas in the Aralkum. This salty desert is the main source of salt and dust storms in Central Asia. The intensive salt transportation from this area is one of the most negative manifestations of the Aral disaster. Salt and dust storms cause the increase of the soil, surface and ground water salinity 
in the areas of salts sedimentation, degradation of the pastoral and agricultural vegetation. Significant deterioration of the environment in Dashkhovuz velayat is caused not only by the influence of the drying Aral Sea, but also by the changing quality of the surface water sources including water from the Amudarya River. The main reason of such deterioration is the return of the drainage water into the river. The collector-drainage water from the agricultural fields, as well as industrial and household drainage from the cities, contain salts, mineral fertilizers, pesticides and herbicides, petroleum, fluorine and heavy metals in quantities far exceeding the maximum permitted concentration (MPC).

The processes directly causing the degradation of the environment are often accompanied by considerable deterioration of human life-support. The lifesupport media: water, air, food, soil, all have been changed chemically, toxically and microbiologically.

\subsection{Water pollution}

The population of the Dashkhovuz velayat is in the extreme need of pure fresh water. Most of the families use water delivered to the area from the outside and kept in the tanks. The other sources of water supply are water wells and irrigation canals. In both cases the water is not purified and disinfected. The only kind of water processing is boiling and in some large settlements chlorination. There are 69 water supply systems in the towns of the province, 68 of them don't meet the sanitary standards because of the lack of the necessary purification structures. Water from the water supply systems is available not more than $3-4$ hours in a day $[4,5]$.

Deterioration of the drinking water quality is one of the most unfavorable indicators of desertification. This is especialy manifested in the irrigated regions due to improper fertilization and crop treatment with pesticides and insecticides. Surface water undergoes the greatest changes. The annual volume of drainage water returned to the Amudarya river exceeds $9 \mathrm{~km}^{3}$ with a salinity level of 1 $14.2 \mathrm{~g} \mathrm{l}^{-1}$. As a result, the salinization of river water reaches up to 2-3 $\mathrm{g} \mathrm{l}^{-1}$ in the lower part of the Amudarya River [2]. Besides salts, Amudarya's water contains a large amount of heavy metals: manganese (1.3-2 times MPC), iron (1.5-3.3 times MPC), lead (5-10 times MPC), cadmium (6-8 times MPC); harmful organic compounds: oil products (36-46 times MPC), phenols (400-1000 times MPC); and other toxic compounds [6,7]. Thus, currently Amudarya water in the lower reaches is dangerous for drinking and of low use for irrigation purpose.

Some of the toxic chemicals were revealed in the ground water on the depth of $2-3 \mathrm{~m}$, i.e. on the level of the wells in the countryside. Concentration of hexachlorocyclohexane in the ground water exceeds the MPC by 1.5-3.5 times, metaphos and phasalon - by 5.0 and 50-100 times respectively. Thus, the use of water from the wells is dangerous for the health [8].

The general prophylactic medical check-up of the population of Kunyaurgench district of Dashkhovuz velayat revealed that $81.4 \%$ of it suffer from various diseases; $77.1 \%$ of them are diseases connected with the use of the bad quality drinking water [9]. 


\subsection{Air pollution}

The transfer of the salt dust from the exposed bottom of the Aral Sea to the adjacent areas is one of the most negative current processes. Since 1975, up to ten large-scale dust storms originated in the Aral Sea dry bottom are registered annually by remote sensing means. Analysis of the space images revealed that in $60 \%$ of cases the dust and salt blowouts are moving to the south-west - to oases of Amudarya delta, in $25 \%$ of events - to the west to Ustyurt plateau, and in the rest of cases - to the south and south-east. The length of the dust flows registered by remote sensing images is usually about $200-300 \mathrm{~km}$.

Average annual transfer of salt-dust aerosol from the dried bottom of the Aral Sea is about $1.06 \mathrm{~min}$. ton, it means that layer of $4 \mathrm{~cm}$ from the surface of exposed bottom is being removed during one year [10]. The amount of the raised dust-salt aerosol varies in different years from the hundreds of thousands ton to 20-30 million ton per year [11]. The dust-salt aerosol blown from the dried bottom contain such harmful for the population heavy metals as strontium, zinc, mercury, arsenic, manganese, chromium. The content of the heavy metals in aerosols from the Aral Sea bottom exceeds that of the background by 3-6 times [10]. By this reason the atmospheric air of Dashkhovuz velayat is strongly polluted. There is the clearly expressed tendency to the increase of the dust concentration. In 1994 the average content of the dust in the air was 2.5 of MPC. The content of such polluting substances as nitrogen dioxide, carbon oxide, and sulfuric anhydride at the same period was $1.5,1.3$ and 2.4 of MPC respectively [12]. All these polluting components cause the increase of the rate of bronchial and lung deseases.

\subsection{Other factors of pollution of environment}

The main typical feature of the Aral Sea region is the high rate of pollution of the soil, water and air by dust-salt aerosol and toxic chemical substances. From 200 to $800 \mathrm{~kg} /$ he and more dust and salt sediment in the Dashkhovuz oasis annually. This amount by 30 times exceeds the volume of dust and salt sedimented by natural aeolian way in $1960^{\text {th }}$. Additionally to this amount, about $183 \mathrm{~kg} / \mathrm{he}$ per year of the salts come with atmospheric precipitation, which is 6 times more than in 1975 [8]. The process of the salt transfer in the Aral Sea region has been going on for more than 30 years; thus, such amount of the deposited salts affects significantly the arid ecosystems of the region. It was found out that the upper soil layer of the Aral Sea region contains the salts of heavy metals such as: chromium, lead, boron, cadmium, molybdenum, and quicksilver. The population of the Aral Sea region is affected by pesticide pollution. About 32 toxic chemicals were found in the Aral Sea region. The persistent chlorineorganic compounds such as: dichloro-diphenil-dichloroethane and its metabolites, hexachlorocyclohexane and its g-isomer lindane are found in the Aral Sea region. These compounds are highly toxic and stable in the environment, and they are not used in many countries of the world [13]. 
Thus, the dust-salt transfer and secondary use of the drainage water negatively affect the quality of environment, and, first of all, atmospheric air, surface and ground water including drinking water, and soils. As a result, the quality of the plant breeding and livestock breeding products is decreasing, and the living conditions and health of the local population are deteriorating. Levels of sickness of such diseases as hepatitis, intestinal and respiratory diseases have increased especially among children $[14,15,16,17,18,19]$.

\section{Health status of mothers and children in Dashkhovuz velayat}

The health of population is in the balance with natural and social conditions. Destroying or deterioration of the environment leads to the increasing morbidity and birth deformities. Especially negative effect on the health of children and pregnant women have air and water sources pollution, and lack of the clean food products. The supply of the good quality drinking water is a particular complicate problem in Turkmenistan. The rural population suffer from the lack of pure water at the greatest extent. Analasis of maternal mortality showed that $15 \%$ of the deceased women lived in the large towns with relatively set up everyday life, $85 \%$ of them lived in the urban settlements, among them $70 \%$ - in the rural areas.

More than 30 thousand of the rural dwellers use the water from the wells, $60 \%$ of which don't meet the sanitary standards. 100,000 of rural population live in the area without the wells and have to use water from the irrigation system ("aryks") for housekeeping and drinking.

The environment in the Aral region has being changed in the space of one generation, while adaptation of the human organism to the changing natural conditions takes more time. Analysis of the data on children's morbidity and mortality in the area demonstrates the predominance of the acute intestinal diseases. Each second-third child suffers from these kind of diseases in the early age. Consequently, the girls are growing and preparing to the motherhood with already sick alimentary canal. It leads to the derangement of the absorbability of necessary for the normal vital activity substances, particularly iron. By the deficit of the latter the anaemia is developing; this disease is widely distributed among pregnant women of Dashkhovuz velayat. The medical check-up of the fertile age and pregnant women has revealed the deficit of iron in $45 \%$ and $87 \%$ of cases respectively, deficit of folic acid in $54 \%$ and $86 \%$ of cases respectively. Polyvitamin deficiency in combination with iron deficit seriously affects the health of women and children. Anaemia is resulting in weakening of the organism, immune depression, hypotrophy, premature births and disturbances of the children's maturity.

\subsection{Health status of the fertile age women}

Dispanserisation of the fertile age women in Dashkhovuz velayat has shown that anaemia is in the first place in the sickness structure of this group of population - 
9,040 of cases per 100,000 . Microelement disbalance of the drinking water and deficit of proteins in the ration is one of the main reasons of this pathology.

Rate of the sickness of alimentary canal (including chronic hepatitis) is 5 times higher than in Ashgabat, the capital city of Turkmenistan. In practice, each third woman in reproductive age with disease of alimentary canal suffered (in most of the cases during pregnancy) from the virus hepatitis $\mathrm{E}$. It is caused by the bad quality water and the lack of reliable means for desinfection of drinking water. The level of sickness of the urinogenital canal among the female population of velayat is also rather high - seven times higher than in Ashgabat. Analysis of urine of the females in Dashkhovuz has revealed that the lead content is 3 times the average in Turkmenistan.

Endocrine diseases, including those of thyroid gland, constitute 7,004.2 cases per 100,000 which is more than 9 times higher than in Ashgabat. The per centage of this pathology correlates with fluorine and iodine content in the drinking water. Thus, the iodine content in water of the Aral region is 2 times lower the normal. Women of the Aral region suffer from the chronic ovaritis. The rate of this pathology is 4 times higher than in the other areas of Turkmenistan $(27.2 \%$ vs. 6.4\%). The cases of female's sterility are also rather frequent $(9.8 \%)$. The quarter of the sterile women have suffered from infantilism or exhaustion. Thus, only $6 \%$ of the women in fertile age of Dashkhovuz velayat could be considered as healthy.

\subsection{Health status of the pregnant women}

According to the official statistic data the health status of the pregnant women in Dashkhovuz velayat is low. This or other pathology has been observed among $85 \%$ of the women of fertile age, $100 \%$ of pregnant women suffer from extragenital pathology (sometimes from combination of 2-3 diseases). The anaemia of the pregnant women increased in 4.3 times during 5 years - from 118.5 per 100,000 in 1986 to 513.7 per 100,000 in 1990). In 1990 half of the pregnant women suffered from anaemia.

Among the other extragenital diseases the pathology of the thyroid gland is on the first place - 13.1 cases per 1000 of birth giving. In 199282 cases of virus hepatitis of pregnant women were observed.

\subsection{Maternal mortality}

The maternal mortality (MM) is one of the main indicators for assessing the socio-economic level of the region and the health care services. In $1986 \mathrm{MM}$ in Dashkhovuz velayat was 142.1 per 100,000 , i.e. was $38.5 \%$ higher than the average in Turkmenistan. Each third deceased woman was the dweller of this velayat. In $1987 \mathrm{MM}$ decreased by $11.4 \%$ (127.6 cases per 100,000 of population), but still was $27.2 \%$ higher than average. The quarter of the deceased women were dwellers of Dashkhovuz velayat. In 1990 the lowest level of maternal mortality was registered (125.9), which, nevertheless, exceeded the average in the state by $12.7 \%$. During 7 years 187 women died $(27 \%$ of the 
deceased women in Turkmenistan). Most of them die during the 28-week of pregnancy and more.

Distribution of the mortality by the seasons of year shows that $60 \%$ of deaths happen in the spring-summer season, and $40 \%$ - in autumn-winter. The births are distributed more evenly during the year (50.4\% and $49.1 \%$ respectively).

\section{Children's health}

Unfavorable ecological and socio-hygienic conditions in Dashkhovuz velayat and related complications of the pregnancies and confinements, high level of the women's general and gynecologic diseases, pathologies of newborn children negatively affect the health status of the infants and children of the early age.

The medical check-up of the children has revealed the significant distribution of such diseases as rachitis, hypotrophy, anaemia, and exudative catarrhal diathesis. $71.4 \%$ of infants suffer from rachitis, $85 \%$ - from exudative catarrhal diathesis, $28.5 \%$ - from anaemia, and $12.6 \%$ - from underfeeding. The level of sickness among the infants is $81.3 \%$.

The diseases of prenatal period were the main cause of infant mortality in Turkmenistan in 1986-1992. The index of infant mortality in Dashkhovuz velayat is the highest in Turkmenistan. The rate of neonatal mortality is increasing during the last years. The prenatal mortality in $70 \%$ of cases is caused by stillbirth, and in $30 \%$ - by early neonatal mortality.

Widely distributed in Dashkhovuz velayat hepatitis $E$ is one of the causes of premature births. $27.7 \%$ of premature babies, whose mothers were not treated during pregnancy, died.

In the structure of early neonatal morbidity the pneumonia is in the first place. Infectious and respiratory diseases are in the second and third place respectively. Infants suffer first of all from the intestinal infections. It is caused by the high air temperatures in summer, and unfavorable ecological and socio-hygienic conditions.

The index of early neonatal mortality varies from $44.4 \%$ to $87.3 \%$. Additionally to the environmental status, the socio-economic factors and index of the women's health influence this parameter.

Level of morbidity of the 3-6 years old children is 18,549 per 100,000 of the children of the same age. Anaemia is in the first place in the morbidity structure, diseases of alimentary canal and respiratory diseases are in the second and third place.

\subsection{Infant mortality}

Statistic data and data of our observations shows the high level of infant mortality in Turkmenistan (58.2 in 1986 and 43.8 in 1992). In Dashkhovuz velayat this index is even higher (76.3 in 1986 and 52.4 in 1992).

Study of seasonality of the infant mortality during first year of the life shows that $27.4 \%$ of all cases occur in winter, and $25.5 \%$ - in summer season. Intestinal diseases are the main cause of the infant mortality in summer time, and 
respiratory diseases - in winter time. In 1986-1992 the acute intestinal infections and sepsis dominated. $90.7 \%$ of children of the first year of life died because of infectious diseases. The analysis of the causes of infants' deaths evidence that the level of exogenous causes of the deaths such as respiratory, infectious, and parasitic diseases, is very high [14].

\subsection{Health status of schoolchildren and adolescents}

The medical check-up of 1147 children at the age from 7 to 14 years old revealed, that $61.5 \%$ of children suffer from the diseases of digestive organs, $32.2 \%$ - from the blood diseases, and $18.8 \%$ - from the respiratory ducts diseases. $7.7 \%$ of children suffer from the diseases of the nervous system already at the 8 years old age. Later, at the older age, this pathology rises to the third place, while the diseases of digestive organs and blood diseases remain in the first and second place mainly because of anaemia. Respiratory ducts diseases are on the fourth place, and endocrine diseases, disturbances of metabolism and immune depression are on the fifth place [14].

In Dashkhovuz velayat the adolescent girls have lower characteristics of the physical and puberty maturity than the girls from the other areas of Turkmenistan. There is a specific for the Aral region morphological type of the children's organism: short stature and small weight, the wide chest and narrow pelvis. The polluted air negatively affects the respiratory and cardiovascular systems. It is expressed in the change of the size of the lungs, and passibility of the trachea and bronchial canals. Decrease of passibility of the bronchial canals under conditions of high dust content of the air favors the increasing of bronchial pathology among children, such as tuberculosis, bronchitis, and pneumonia.

\section{Conclusions}

Unfavorable social-economic consequences of desertification are manifested in deterioration of public health. Increase in the morbidity rate is primarily due to the bad quality of drinking water and the high level of air pollution. The desertification processes negatively affect the population in several generations. The birth rate is decreasing, and the disease incidence and death-rate (especially infantile mortality) are increasing.

The significant distribution of such background diseases as rachitis, hypotrophy, anaemia, exudative catarrhal diathesis was revealed in the Dashkhovuz velayat. $71.4 \%$ of children on the first year of their life suffer from rachitis, and $85 \%$ - from exudative catarrhal diathesis. Feeding derangement was observed in $42.6 \%$ of children, anaemia $-28.5 \%$. The level of morbidity of the infants is $81.3 \%$. The leading place in the morbidity structure of children of the first 3 years of life has the respiratory diseases. Infant mortality in Dashkhovuz velayat is $57.9 \%$ on first year of life, and $17.3 \%$ - on the second year. Among the reasons of such high rate of mortality the intestinal infections has the leading place. 
This or other pathology was observed among $85 \%$ of the women of fertile age, extragenital pathology - in $100 \%$ of pregnant women. The main reason of women's morbidity is anaemia and diseases of alimentary canal. Mother's mortality in Dashkhovuz velayat is $38.5 \%$ higher than the average in Turkmenistan.

The goverment of Turkmenistan makes some efforts to provide the people with better quality drinking water, medical service, and to improve communal infrastructure. However, current financial constraints associated with the transition period and re-arrangement of national economy to the market model don't allow to solve this problem in the near future.

\section{References}

[1] Klees, R. World Bank project in watersupply and sanitary in Tashauz velayat, Turkmenistan. Problems of desert development, 1, pp. 13-17, 1997.

[2] UNCED, United Nations Conference on Environment and Development. Rio de Janeiro, June 1-12, 1992.

[3] Chembarisov, E. I. Estimation of volume and quality of the collector drainage waters of the Central Asia. Problems of desert development, 3-4, pp. 156$159,1998$.

[4] Illiev, S.Kh. Water and health of the population. Problems of desert development, 1, pp. 22-26, 1997.

[5] Maktav, S. Water supply and children's health state in Tashauz velayat. Problems of desert development, 1, pp. 34-38, 1997.

[6] Kolodin, M.V. Water resources in Central Asia and the problem of Aral Sea. Problems of desert development,4-5, pp. 73-87, 1994.

[7] Orlovsky N.S., Glantz M., \& Orlovsky L. Irrigation and Land Degradation in the Aral Sea Basin. Sustainable Land Use in Deserts, eds., Breckle S.-W., Veste M., and Wucherer W. Springer-Verlag: Berlin and New York, pp. 115-125, 2001

[8] Esenov, P. Environment contamination in Tashauz velayat. Problems of desert development, 1, pp. 38-44, 1997.

[9] Gutliev, Kh. Water supply state in Kunyaurgentch etrap. Problems of desert development, 1, pp. 52-53, 1997.

[10] Toleubaev, S.I. \& Bogdanov, L.A. The degree of pollution of drained bottom of the Aral Sea by heavy metals and pesticides. Problems of Desert Development, 3-4, pp. 186-187, 1998.

[11] Galaeva, O.S. About monitoring of carrying out of sandy salt aerosol from drained part of bottom of the Aral Sea. Problems of desert development, 34, pp. 17-21, 1998.

[12] Kurbanov, P.K. Nature-protection questions in Tashauz velayat. Problems of desert development, 1, pp. 10-13, 1997.

[13] Muminov T., \& Seysebaeva R. The formation of chronic diseases of respiratory tract in children of the Aral Sea region. Sustainable Use of natural Resources of Central Asia, Tethys, Almaty, pp.162-164, 1998. 
[14] Radzinsky, V.E., (ed.). Health of mother and child in Pre-Aral of Turkmenistan, Zdorov'e: Kiev, 1994.

[15] Sergiev, V.P., Beer, S.A., Elpiner, L.I. \& Vinogradov, V.G. (eds). Medical and ecological aspects of the Aral Sea crisis. VINITI: Moscow, 1993.

[16] UNEP. Diagnostic study for the preparation of on action for the rehabilitation of the Aral Sea. UNEP: Nairobi, 1992.

[17] Downing, D. Health consequences of the Pre-Aral disaster. Journal of Nitrition and Environmental Medicine, 5, pp. 391-399, 1995.

[18] Elpiner, L.I. Public health in the Aral Sea coasral region and the dynamics of changes in the ecological situation. Creeping Environmental Problems and Sustainable Development in the Aral Sea Basin, ed. M. Glantz, Cambridge University Press: Cambridge,pp. 128-156, 1999.

[19] Kiessling, K.Z. Conference on the Aral Sea - women, children and environment. Ambio, 277, pp. 560-564, 1998. 